\title{
Changes in sour rotten grape berry microbiota during ripening and wine fermentation
}

\author{
André Barata *, Manuel Malfeito-Ferreira, Virgílio Loureiro \\ Laboratório de Microbiologia, Departamento de Recursos Naturais Ambiente e Território, Centro de Botânica Aplicada à Agricultura, Instituto Superior de Agronomia \\ Technical University of Lisbon, Lisboa, Portugal
}

\section{A R T I C L E I N F O}

Article history:

Received 18 July 2011

Received in revised form 18 November 2011

Accepted 22 December 2011

Available online 8 January 2012

\section{Keywords:}

Damaged grapes

Sour rot

Yeasts

Acetic acid bacteria

Lactic acid bacteria

Wine fermentation

\begin{abstract}
A B S T R A C T
This study investigated the microbiota of sour rotten wine grapes and its impact on wine fermentations. Yeasts, lactic acid bacteria ( $L A B)$ and acetic acid bacteria (AAB) were enumerated and identified on sound and sour rot grapes during the ripening stage. The alteration of the ecological balance induced by sour rot was particularly evidenced by the unequivocal increase of yeast and $A A B$ counts on rotten grapes, since the beginning of ripening. Yeast and $A A B$ species diversity in rotten grape samples were much higher than those found in sound grapes. LAB populations were low detected from both healthy and sour rotten grapes. The yeast species Issatchenkia occidentalis, Zygoascus hellenicus and Zygosaccharomyces bailii and the AAB species Gluconacetobacter hansenii, Gluconacetobacter intermedius and Acetobacter malorum, were recovered from damaged grapes and resulting grape juices in the winery. Acetobacter orleaniensis and Acetobacter syzygii were only recovered from sour rotten grapes.

Dekkera bruxellensis and Oenococcus oeni were only recovered after wine fermentation induced by starter inoculation, irrespective of grape health, probably originating from cellar environment. After malolactic fermentation, racking and sulphur dioxide addition the only remaining species were the yeast Trigonopsis cantarellii and Saccharomyces cerevisiae, independently of the grape health status.
\end{abstract}

(c) 2011 Elsevier B.V. All rights reserved.

\section{Introduction}

Grape quality may be affected by a wide range of rots. Among them, sour rot is an emergent grapevine disease affecting late ripening cultivars with tightly-packed, thin-skinned and dense bunches close to harvesting, causing heavy crop losses and being detrimental to juice and wine quality (Bisiach et al., 1986; Wolf et al., 1990; Zoecklein et al., 1992). Rotten bunches have a strong and pungent odour of vinegar as a result of the production of high levels of acetic acid, accompanied by high concentrations of glycerol, ethyl acetate, ethanol, acetaldehyde and galacturonic and gluconic acids (Marchetti et al., 1984; Zoecklein et al., 2001). These products are the result of a mixed population of yeasts and acetic acid bacteria (AAB) (Acetobacter spp. and Gluconobacter spp.) (Bisiach et al., 1986; Blancard et al., 2000; Gravot et al., 2001).

Berry rupture is associated with a sudden increase in yeast load up to about $10^{6}-10^{8} \mathrm{CFU} / \mathrm{g}$ and deep alterations in species diversity occur when compared with sound grapes (Barata et al., 2008a,b). The main yeast species recovered from sour rotten grapes are Candida krusei, Issatchenkia orientalis, Kloeckera apiculata/Hanseniaspora

\footnotetext{
* Corresponding author at: Laboratório de Microbiologia, Departamento de Recursos Naturais Ambiente e Território, Instituto Superior de Agronomia, 1349-017 Lisboa, Portugal. Tel.: + 351213653448 ; fax: + 351213653238 .

E-mail address: abbarata@isa.utl.pt (A. Barata).
}

uvarum, Saccharomycopsis vini, Candida steatolytica (syn. Zygoascus hellenicus), Torulaspora delbrueckii, Issatchenkia terricola and Zygosaccharomyces bailii (Barata et al., 2008a,b; Bisiach et al., 1982; 1986; Guerzoni and Marchetti, 1987; Guerzoni and Marchetti, 1982; Marchetti et al., 1984). The population size of AAB on healthy grapes is typically low $\left(10^{2}-10^{3}\right.$ cells $\left./ g\right)$ and Gluconobacter oxydans is the species most represented, while in grapes damaged by Botrytis cinerea (grey rot), AAB populations can reach up to $10^{5}-10^{6}$ cells $/ \mathrm{g}$, comprising Gluconobacter spp. and Acetobacter spp., mainly A. aceti and A. pasteurianus (Barbe et al., 2001). Undamaged grapes contains low populations of $\mathrm{LAB}$, not exceeding $10^{3} \mathrm{CFU} / \mathrm{g}$ and the initial titer in must is low (Bae et al., 2006; Fugelsang, 1997; Lafon-Lafourcade et al., 1983). Only a few LAB species of the genera Lactobacillus spp. (Lb.), Leuconostoc spp. (Lc.), Pediococcus spp. (P.), Oenococcus spp. (O.) and Weissella spp. (W.) can grow in must and wine (König and Fröhlich, 2009). The species Oenococcus oeni, regarded as the main agent of malolactic fermentation (Henick-Kling, 1993; LonvaudFunel, 1995, 1999) has been seldom isolated from grapes in the vineyard (Renouf et al., 2007). Several other bacterial species have also been isolated from sound and grey rotten grapes (Nisiotou et al., 2011). However, these species have no technological significance in winemaking, being probably only a result of environmental contamination of berry surfaces.

Previous work from our laboratory, based on accurate berry sampling, has shown that grape damage by sour rot induced dramatic 
increases on yeast counts and number of species since the beginning of grape ripening (Barata et al., 2008a,b). However, the knowledge of the complex microbial changes that lead to sour rot disease has not yet been completed and clearly understood, particularly in regard to the role and evolution of bacterial populations. Therefore, the purposes of this work were (i) to investigate the changes of the overall grape contaminants including yeasts, AAB and LAB populations present on healthy and sour rotten berries surfaces during different stages of ripening, and (ii) to study the fate of these populations during winemaking at winery level. For that, a careful berry sampling followed by isolation and enumeration on both general purpose media and selective and differential media, together with identification by molecular methods, were performed.

\section{Material and methods}

\subsection{Grape samples}

During the 2007 vintage, healthy and sour rot affected bunches of Vitis vinifera L. cv. Trincadeira red grape variety were selected from a experimental vineyard of Instituto Superior de Agronomia, located in Tapada da Ajuda, Lisbon, Portugal (latitude $38^{\circ} 42^{\prime} 31.57^{\prime \prime} \mathrm{N}$ and longitude $9^{\circ} 11^{\prime} 14.01^{\prime \prime} \mathrm{W}$ ). Just after the veraison period, the Trincadeira parcels were visually inspected and vines containing bunches with sour rot symptoms were marked. Two sets of three different vines (duplicates) were selected for taking samples of sound and sour rot affected bunches at 3 different ripening phases: i) after veraison (10 August 2007); ii) middle of ripening (22 August 2007); and iii) harvest time (7 September 2007). A total of 3 bunches from each vine set were aseptically collected and transported to the laboratory in sterile bags at $5{ }^{\circ} \mathrm{C}$. Individual grape berries were randomly and aseptically removed from the bunches and combined to give a total of 100 sound berries plus 100 damaged berries.

The berries were placed in a sterile stomacher bag and crushed in a stomacher blender (IUL, Barcelona, Spain). The obtained grape juices from each phase were subsequently used for the microbiological analyses.

\subsection{Experimental wines}

Sound and sour rotten Trincadeira grape bunches were handharvested at time of full maturation in the same experimental vineyard, carefully separated in different $20 \mathrm{~kg}$ plastic boxes and transported to the experimental cellar of Instituto Superior de Agronomia, located $700 \mathrm{~m}$ distance from the vineyard (latitude $38^{\circ} 42^{\prime} 26.36^{\prime \prime} \mathrm{N}$ and longitude $9^{\circ} 10^{\prime} 57.39^{\prime \prime} \mathrm{W}$ ).

Microvinification sets of $100 \%$ sound Trincadeira grapes (control sets) and Trincadeira musts containing $30 \%$ of sour rotten grapes were performed in $50 \mathrm{~kg}$ capacity stainless steel vats ( $30 \mathrm{~kg}$ of grapes per set). Firstly, sound bunches were combined to give a total of $60 \mathrm{~kg}$ of grapes and later sound and sour rotten bunches were weighed and mixed in order to obtain a total of $60 \mathrm{~kg}$ of a grape mixture containing 30\% sour rotten grapes. Rotten bunches were visually inspected and only the rotten parts of the bunch were selected for the mixture. Afterwards, both grape blends were mechanically destemmed and crushed on a commercial grape destemmer-crusher. The equipment was disinfected between operations. The resulting grape musts were divided into different vats ( $30 \mathrm{~kg}$ each).

A $50 \mathrm{~mL}$ sample of both $100 \%$ sound and $30 \%$ sour rotten grape musts were collected and transported for the laboratory for immediate microbiological analyses.

In order to evaluate the effect of the initial vatting sulphur dioxide $\left(\mathrm{SO}_{2}\right)$ concentration on the must microbial flora and further wine microbial stability, both grape musts sets were added with $30 \mathrm{mg} / \mathrm{kg}$ and $100 \mathrm{mg} / \mathrm{kg}$, using an aqueous solution of $\mathrm{SO}_{2}(6 \% \mathrm{w} / \mathrm{v})$. A prefermentative maceration period $(18 \mathrm{~h})$ was performed at cellar temperature $\left(18 \pm 2{ }^{\circ} \mathrm{C}\right)$, followed by inoculation of musts with $10^{6}$ cells $/ \mathrm{mL}$ of selected commercial Saccharomyces cerevisiae yeast (Fermivin ${ }^{\circledR}$, DSM, Delft, The Netherlands). Alcoholic fermentations took place at cellar temperature and the cap was punched down twice a day until it remained submerged. After completion of fermentation, the resulting wines (free run and press wines obtained from pomace pressing) were transferred to clean $20 \mathrm{~L}$ glass carboys, where it underwent spontaneous malolactic fermentation (MLF) at cellar temperature. Degradation of malic acid was monitored through paper chromatography (Ribéreau-Gayon et al., 1972). Once MLF was completed, wines were racked (lees were removed) and free $\mathrm{SO}_{2}$ levels were adjusted to $40 \mathrm{mg} / \mathrm{L}$. After one week, wines were bottled without filtration in 0.75 L glass bottles capped with natural corks and kept at cellar temperature. Microbiological analyses were performed in three different stages of winemaking: i) vatting (initial grape must); ii) just after alcoholic fermentation; and iii) after MLF and addition of sulphur dioxide.

\subsection{Microbiological analyses}

\subsubsection{Enumeration and isolation of yeasts from grapes}

The microbial populations of yeasts were studied on grape musts samples obtained from sound and sour rotten grapes during ripening. Just after berries crushing (100 berries sample), grape musts were decimally diluted $\left(10^{-1}\right.$ to $\left.10^{-6}\right)$ in peptone water (Merck, Darmstadt, Germany). The enumeration and isolation of yeasts was carried out by surface plating $(0.1 \mathrm{~mL})$ of the adequate dilutions onto plates (duplicates) of several culture media: i) general purpose medium GYP agar, composed by $20 \mathrm{~g} / \mathrm{L}$ glucose (Merck), $5 \mathrm{~g} / \mathrm{L}$ yeast extract (Oxoid, Hampshire, UK), $5 \mathrm{~g} / \mathrm{L}$ peptone (Difco Laboratories, Detroit, USA), $20 \mathrm{~g} / \mathrm{L}$ agar, pH 6.0, supplemented with $100 \mathrm{mg} / \mathrm{L}$ of chloramphenicol (Sigma, Steinheim, Germany) and $0.5 \mathrm{~g} / \mathrm{L}$ of biphenyl (Fluka, Buchs, Switzerland) to avoid growth of bacteria and moulds, respectively; ii) selective/differential media DBDM and ZDM for the isolation of Dekkera/Brettanomyces and Zygosaccharomyces species, respectively, or other non-Saccharomyces species as previously reported by (Barata et al., 2008a,b). Total yeast enumeration was obtained from the GYP plates, recording the number of colony forming unit (CFU) counts.

In case of Dekkera/Brettanomyces species, a secondary procedure was performed using the enrichment medium EBB (Renouf and Lonvaud-Funel, 2007). Fifty berries randomly selected from each grape sample were placed in a $500 \mathrm{~mL}$ Erlenmeyer flask containing $170 \mathrm{~mL}$ EBB broth. Berries were incubated at $30{ }^{\circ} \mathrm{C}$ in an orbital shaker (Agitorb 200IC, Aralab, Lisbon, Portugal) at $80 \mathrm{rpm}$ for 10 days. After the enrichment step, the medium was decimally diluted $\left(10^{-1}\right.$ to $\left.10^{-6}\right)$ in peptone water and yeasts were recovered by spreading $0.1 \mathrm{~mL}$ (duplicates) of the appropriate dilutions onto GYP, DBDM and ZDM plates. Plates were incubated at $25{ }^{\circ} \mathrm{C}$ during 7 days (GYP) and up to 15 days (DBDM and ZDM).

Following incubation, all media plates containing countable yeast colonies ( 1 to 300 ) were examined, all different colony morphological types were registered, differentially counted and two to five representative isolates from each morphology were selected for identification. When colonies from the same type were identified as different species, the respective proportion was changed accordingly. All isolates were streaked and purified on GYP plates. After purification, yeast isolates were preserved on YM agar slants ( $3 \mathrm{~g} / \mathrm{L}$ yeast extract, $3 \mathrm{~g} / \mathrm{L}$ malt extract, $5 \mathrm{~g} / \mathrm{L}$ peptone, $10 \mathrm{~g} / \mathrm{L}$ glucose, $20 \mathrm{~g} / \mathrm{L}$ agar) until their later analysis, stored at $4{ }^{\circ} \mathrm{C}$ and subcultured every month.

\subsubsection{Enumeration and isolation of $A A B$ and $L A B$ from grapes}

The enumeration of $A A B$ and $L A B$ was carried out using the Most Probable Number (MPN) technique (OIV, 2010). Briefly, grape musts samples were decimal diluted until extinction $\left(10^{-1}\right.$ to $\left.10^{-7}\right)$, and $1-\mathrm{mL}$ portion of must $\left(10^{0}\right)$ and $1-\mathrm{mL}$ of each dilution, 
were inoculated into three tubes containing $3 \mathrm{~mL}$ of $\mathrm{GY}[50 \mathrm{~g} / \mathrm{L}$ glucose, $10 \mathrm{~g} / \mathrm{L}$ yeast extract, and $13 \mathrm{~g} / \mathrm{L}$ agar, $200 \mathrm{mg} / \mathrm{L}$ Delvocid $\AA$ (DSM, Delft, Netherlands) (100 mg/L natamycin), $3000 \mathrm{U} / \mathrm{L}$ penicillin (Sigma), pH 4.5] and $5 \mathrm{~mL}$ of MRS [ $52 \mathrm{~g} / \mathrm{L}$ MRS (Oxoid), $200 \mathrm{mg} / \mathrm{L}$ Delvocid $\AA, 0.5 \mathrm{~g} / \mathrm{L}$ L-cysteine (Sigma)] broths, for enumeration of $A A B$ and $L A B$, respectively. Delvocid ${ }^{\circledR}$ and penicillin were used to inhibit the growth of yeasts and $\mathrm{LAB}$, respectively. Inoculated tubes were incubated at $28{ }^{\circ} \mathrm{C}$ during 8 days (up to 10 days), under aerobic conditions, for $\mathrm{AAB}$, and under microaerophilic conditions, by addition of $500 \mu \mathrm{L}$ sterile paraffin oil (Sigma), for LAB, making periodic observations up to the last day of incubation. All those tubes that showed a microbial development leading to the formation of a more or less evident whitish deposit and/or disturbance were considered as positive. Results were confirmed by microscopical observation.

Bacterial isolates were obtained by streaking an aliquot $(10 \mu \mathrm{L})$ of all tubes with visible growth in agar plates containing the respective isolation medium. Plates were incubated at $28{ }^{\circ} \mathrm{C}$ up to 8 days. The different colony/cell morphologies found in each positive tubes of each dilution were registered and representative isolates, as mentioned before for yeasts, were purified, by restreaking on the respective GY or MRS plates and selected for molecular identification. For long term storage, purified isolates were maintained frozen at $-80{ }^{\circ} \mathrm{C}$ in vials containing the isolation liquid medium with $15 \%(\mathrm{v} / \mathrm{v})$ glycerol (Merck), until their later analysis. After identification, enumeration (MPN/mL) of each recovered species was obtained by using the statistical tables and rules presented in OIV 206/2010 Resolution (OIV, 2010). Gram staining and catalase production tests, were conducted for all bacterial isolates.

\subsubsection{Yeasts, $A A B$ and $L A B$ enumeration and isolation during wine fermentations}

This study was also conducted for the vinification samples (initial vatting grape musts and final wines) on each previously described winemaking phase. Initial vatting grape musts and wine samples were decimally diluted $\left(10^{-1}\right.$ to $\left.10^{-7}\right)$ in peptone water (Merck). The enumeration and isolation of yeasts were carried out by surface plating $(0.1 \mathrm{~mL})$ of the adequate dilutions onto plates (duplicates) of GYP, DBDM and ZDM, as described previously. In case of wine samples just after alcoholic fermentation and MLF, additional GYPC plates [20 g/L glucose (Merck), $5 \mathrm{~g} / \mathrm{L}$ yeast extract (Oxoid), $5 \mathrm{~g} / \mathrm{L}$ peptone (Difco), $20 \mathrm{~g} / \mathrm{L}$ agar, $10 \mathrm{mg} / \mathrm{L}$ of cycloheximide (Sigma), pH 6.0] were also used in order to inhibit the growth of $S$. cerevisiae species. The usual species contaminating fermentations are not inhibited by $10 \mathrm{mg} / \mathrm{L}$ cycloheximide (Rodrigues et al., 2001). Plates were incubated at $25{ }^{\circ} \mathrm{C}$ during 7 days (GYP and GYPC) and up to 15 days (DBDM and ZDM). Likewise, the quantification and isolation of $A A B$ and $L A B$ during wine fermentations, were performed by the MPN technique as described before.

\subsection{Identification of yeasts isolates}

Yeast isolates were identified by restriction fragment length polymorphism (RFLP) analysis of the 5.8S-ITS rDNA region (EsteveZarzoso et al., 1999). For the majority isolates, yeast cells were picked from a fresh colony (48-h-old) and re-suspended directly in the PCR mixture. Isolates for which direct amplification from colony could not be performed, the yeast genomic DNA for PCR amplification was isolated as described in Cryer et al. (1975) after a previous enzymatic treatment with liticase $(5 \mathrm{mg} / \mathrm{mL})$. PCR reactions were performed in a Mastercycler personal (Eppendorf, Hamburg, Germany) thermocycler using the primers (ITS1 and ITS4) and conditions described in Esteve-Zarzoso et al. (1999). Lengths of amplification products and restriction fragments were determined by comparison with 100-bp DNA ladder (Bioron) using the Quantity One 1-D analysis software (BioRad). Restriction patterns generated were recorded and compared with those contained in the Yeast-id database at www.yeast-id.com (Valencia University and CSIC, Spain).

The isolates sharing similar restriction patterns or with misidentified patterns, were grouped and only representative isolates of each case were identified by sequencing the D1/D2 domains of the 26S rRNA gene (Kurtzman and Robnett, 1998). Sequences were edited and assembled using BioEdit Sequence Alignment Editor version 7.0.1 software (Hall, 1999), and then subjected to the GenBank BLASTN search tool of the NCBI database (http://ncbi.nlm.nih.gov/ blast) to retrieve sequences of closely related taxa.

The cluster $H$. uvarum/H. guilliermondii/H. opuntiae was differentiated by growth on GYP agar plates incubated at $37^{\circ} \mathrm{C}$ (Smith, 1998) and by restriction of 5.8S-ITS region with Ddel and Dral (Bioron) endonuclease in accordance with Cadez et al. (2002) and Nisiotou and Nychas (2007), respectively. The Lachancea clade former species (L. fermentati, L. cidri, L. thermotolerans and $L$. waltii) were differentiated by growth on GYP agar plates incubated at $37^{\circ} \mathrm{C}$ and $40^{\circ} \mathrm{C}$, and growth with D-galactose and $0.01 \%$ cycloheximide (Kurtzman, 2003; Kurtzman and Fell, 1998). Pichia deserticola was differentiated from Candida pseudolambica by growth on GYP agar plates incubated at $37^{\circ} \mathrm{C}$ and growth with $50 \%$ D-Glucose (Kurtzman and Fell, 1998). Candida stellata was distinguished from C. zemplinina by digestion of the 5.8S-ITS region with Dral (Bioron) endonuclease in accordance with Sipiczki (2004).

\subsection{Identification of acetic acid bacteria isolates}

Gram-negative and Gram variable, catalase positive isolates recovered from GY broth tubes were considered as putative $A A B$ and selected for identification. The isolates were identified by RFLP of PCR-amplified 16S rRNA gene and RFLP of PCR-amplified 16S-23S ITS region according to González et al. (2006). DNA extraction was carried out using the method described by Ruiz et al. (2000) with the following modifications: fresh cultures were grown on GY plates and 3 to 5 bacterial colonies were picked and re-suspended in $50 \mu \mathrm{L}$ of lysis solution $(0.25 \%$ sodium dodecyl sulphate, $0.05 \mathrm{~N} \mathrm{NaOH})$ and incubated at $100{ }^{\circ} \mathrm{C}$ for $15 \mathrm{~min}$ (boiling water bath). The suspension was cooled at room temperature, centrifuged $\left(5000 \mathrm{~g}, 4{ }^{\circ} \mathrm{C}, 5 \mathrm{~min}\right)$ and the supernatant containing the released DNA was diluted 100fold with sterile miliQ water and used as template for PCR amplification. The 16S rRNA gene and 16S-23S ITS region were amplified using the primers and thermocycling conditions designed by Ruiz et al. (2000). PCR amplifications were carried out in $50 \mu \mathrm{L}$ reaction volume, consisting of $2 \mu \mathrm{L}$ bacterial DNA lysate and $48 \mu \mathrm{L}$ amplification mixture, containing $10 \mu \mathrm{L}$ of $5 \times$ amplification buffer Green Go Taq Flexi (Promega), $200 \mu \mathrm{M}$ of dNTPs mixture, $2 \mathrm{mM} \mathrm{MgCl}_{2}$, $0.3 \mu \mathrm{M}$ of each primer and 2.5 U Go Taq ${ }^{\circledR}$ (Promega). For the restriction reactions of the $16 \mathrm{~S}$ rRNA gene-amplified products, $5 \mu \mathrm{L}$ of each PCR product was digested with $10 \mathrm{U}$ of AluI (Fermentas, Thermo Fisher Scientific Inc., Leicestershire, UK), CfoI, Hinfl, HaeIII, Tru9I (Bioron) and TaqI (Metabion, Martinsried, Germany) restriction endonucleases, as recommended by the manufacturers.

Isolates inconclusively identified by RFLP of 16S rRNA gene as Gluconacetobacter europaeus/Ga. xylinus/Ga. intermedius/Ga. saccharivorans and Acetobacter cerevisiae/A. orleaniensis/A. malorum, were resolved by RFLP of 16S-23S ITS region and by sequencing of both 16S rRNA gene and 16S-23S ITS region. In case of the Gluconacetobacter species the amplified 16S-23S ITS product $(5 \mu \mathrm{L})$ was digested with PvuII (Fermentas) endonuclease, as described by Sievers et al. (1996), while the three Acetobacter species were separated using AluI and CfoI endonucleases (González et al., 2006). The PCR products and restriction fragments were detected and separated by $1.0 \%(\mathrm{w} / \mathrm{v})$ and $3.5 \%(\mathrm{w} / \mathrm{v})$ agarose gel electrophoresis in $1 \times$ TBE buffer, respectively. Restriction patterns were obtained after 
estimation of fragment sizes by comparing their mobility against a 100-bp DNA Ladder (Bioron), as described above.

Sequencing reactions were performed with the same direct and forward primers used for PCR amplification of both regions. The obtained sequences were corrected and later aligned in the GenBank database using the BLASTn algorithm, as previously described.

\subsection{Identification of lactic acid bacteria isolates}

Isolates obtained from positive growing MRS tubes were firstly assigned as presumed LAB on the basis of their character Gram + and catalase negative. Those isolates were initially characterized and grouped in terms of the molecular patterns obtained by 16SARDRA (Amplified Ribosomal DNA Restriction Analysis) for presumptive identification at species level, as described by Rodas et al. (2003).

Prior to PCR amplification, the isolates were grown on MRS plates supplemented with L-cysteine $(0.5 \mathrm{~g} / \mathrm{L})$ at $28{ }^{\circ} \mathrm{C}$ for $2-3$ days, and 2 to 3 fresh colonies were picked and suspended in $50 \mu \mathrm{L}$ of lysis solution following the same strategy previously described for DNA extraction of AAB isolates. The $16 \mathrm{~S}$-rDNA was amplified using the primers ( $\mathrm{pA}$ and $\mathrm{pH}$ ) and PCR conditions described in Rodas et al. (2003). DNA amplification was carried out in $50 \mu \mathrm{L}$ PCR mixture containing $10 \mu \mathrm{L}$ of $5 \times$ amplification buffer Green Go Taq Flexi (Promega), $200 \mu \mathrm{M}$ of dNTPs mixture, $2 \mathrm{mM} \mathrm{MgCl}, 0.5 \mu \mathrm{M}$ of each primer and $2.5 \mathrm{U}$ Go Taq ${ }^{\circledR}$ (Promega). Restriction of the amplified 16S-rRNA gene was carried out using FspBI and MseI (Fermentas) endonucleases, selected as the most discriminative enzymes in accordance to Rodas et al. (2003). PCR products $(5 \mu \mathrm{L})$ were digested overnight with $10 \mathrm{U}$ of each enzyme and the obtained restriction fragments were separated and analysed following the same procedure described for the AAB identification. Representative isolates from each restriction pattern were then selected for sequencing of partial 16S rDNA, using pA and $\mathrm{pH}$ primers, in order to confirm the restriction analysis results and to establish the LAB isolates final identity at species level. The amplified 16S rDNA fragments were purified, sequenced and the final corrected sequences were submitted to the BLASTN network service.

\subsection{Nucleotide sequences accession numbers}

Nucleotide sequences were deposited in the NCBI GenBank database library under the accession numbers JF749205-JF749219, JF718412-JF718428 and JF718430-JF718436 (Table S1).

\section{Results and discussion}

\subsection{Isolation and identification of yeasts, $A A B$ and $L A B$}

A total of 203 yeasts isolates, recovered from sound and rotten grape samples during the 3 ripening phases, and 97 yeast isolates obtained from grape musts and wine samples throughout the 3 winemaking phases, were selected for identification. A total of 15 species were successfully identified by comparison of the CfoI, HaeIII and Hinfl restriction profiles contained in the Yeast-id database (see Table S1 in supplementary material). The Dral endonuclease enabled the identification of C. zemplinina while $H$. uvarum and $H$. guilliermondii were distinguished by DdeI and DraI restriction profiles. P. deserticola and Lachancea thermotolerans were identified by additional biochemical tests. The remaining 10 species were identified by sequencing of D1/D2 domains of the large subunit 26S rRNA gene and respective accession numbers deposited in GenBank (see Table S1).

The AAB and LAB populations were recovered using the MPN technique, which is an advisable approach for the quantification of wine microbial consortium, in samples where moulds or environmental bacteria are numerous (Loureiro et al., 2004). A total of 76 and 74 $A A B$ isolates, representative of the diversity found in all positive GY tubes, were obtained throughout grapes maturation and during the three winemaking phases, respectively. The digestion of the PCR amplified 16S rRNA with six restriction enzymes (AluI, CfoI, Hinfl, HaeIII, Tru9I and TaqI) yielded 5 different restriction patterns (I, II, VI, VII and XI) characteristic of a single species, which were successfully associated with Acetobacter aceti, A. syzygii, A. tropicalis, G. oxydans and Gluconacetobacter hansenii as described by González et al. (2006) (see Table S2 in supplementary material). These identifications, except for $A$. orleaniensis; were confirmed by sequencing of the 16S rRNA gene. Two other patterns were initially inconclusively identified, since they are characteristic of two groups of very closely related $\mathrm{AAB}$ species: A. cerevisiae/A. orleaniensis/A. malorum and Ga. europaeus/Ga. xylinus/Ga. intermedius/Ga. saccharivorans. Therefore, these species were differentiated combining the results obtained by PCR-RFLP of the 16S-23S ITS rRNA gene and sequencing of both $16 \mathrm{~S}$ and 16S-23S ITS rRNA regions. Restriction patterns of the 16S-23S ITS rRNA region were obtained using AluI and Cfol endonucleases for the first group (González et al., 2006) and PvuII (Sievers et al., 1996) for the second group. These molecular approaches allowed the obtention of 6 different restriction patterns (III, IV, V, VIII, IX and X) associated to the species A. cerevisiae (III), A. malorum (IV), A. orleaniensis (V), Ga. europaeus (VIII), Ga. intermedius (IX) and Ga. saccharivorans (X) (see Table S2).

Regarding LAB analysis, a total of 78 isolates representative of the diversity found in all positive MRS tubes were obtained. Within those set of isolates, 40 were considered as putative $L A B$ (Gram positive and catalase negative) and 38 as non-LAB (Gram positive and catalase positive). Four molecular patterns were obtained by 16S-ARDRA using FspBI and MseI endonucleases. Two of them (XIV and XV) matched with the characteristic patterns of Lactobacillus brevis and O. oeni, respectively, as described by Rodas et al. (2003), while the other two were misidentified (XII and XIII). Sequencing of the 16S rRNA gene PCR products were performed for representative isolates of each pattern. Results confirmed the identification of patterns XIV and XV, and revealed 100\% homology with Enterococcus durans, for the pattern XII, and 99\% homology with Enterococcus sp. for the pattern XIII (see Table S2).

The set of non-LAB isolates were separated in two groups in function of its cell and colony morphology, and representative isolates were selected for sequencing of $16 \mathrm{~S}$ rDNA, which allowed the identification of the species Staphylococcus saprophyticus and Kocuria kristinae (see Table S2). Table S3 in supplementary material, shows the patterns obtained with each restriction endonucleases for both PCR-RFLP of the 16S and 16S-23S ITS rRNA regions and 16-ARDRA required to identify the recovered $A A B$ and $L A B$ isolates.

\subsection{Sour rot effect on microbial populations during grape ripening}

The population changes in yeasts, AAB and LAB were analysed since the end of veraison until harvest time on healthy and sour rot grapes. Samples of 100 representative berries of sound and sour rotten grapes, were carefully selected from a set of 3 different bunches collected from 3 different vines, and analysed in duplicate at each ripening phase. The standard deviation of the duplicates was less than $15 \%$ of the mean (results not shown).

\subsubsection{Changes in yeast populations during grape ripening}

A total of 22 yeast species belonging to 10 different genera were identified from healthy and rotten grape samples, of which 3 belong to basidiomycetous yeasts (Table 1 ). In healthy grapes, 7 ascomycetous and 3 basidiomycetous yeasts species were recovered during the 3 maturation phases. Regarding basidiomycetes, the red to pinkish ballistoconidia-forming Sporobolomyces roseus species was isolated since veraison until harvest, while the non pigmented 
Table 1

Changes of yeast populations on healthy and sour rot grapes during ripening. Results reported as log CFU/g and the isolation culture media is shown between brackets.

\begin{tabular}{|c|c|c|c|c|c|c|c|c|c|c|c|c|c|c|}
\hline \multirow{3}{*}{$\begin{array}{l}\text { Sanitary } \\
\text { state }\end{array}$} & \multirow{3}{*}{$\begin{array}{l}\text { Yeast } \\
\text { Basidiomycetes }\end{array}$} & \multirow{4}{*}{$\begin{array}{l}\text { Species } \\
\text { Cryptococcus laurentii } \\
\text { Cryptococcus magnus }\end{array}$} & \multicolumn{4}{|c|}{ After veraison } & \multicolumn{4}{|c|}{ Middle } & \multicolumn{4}{|c|}{ Harvest } \\
\hline & & & \multicolumn{2}{|c|}{ Vine set $\mathrm{A}$} & \multicolumn{2}{|c|}{ Vine set B } & \multicolumn{2}{|c|}{ Vine set $\mathrm{A}$} & \multicolumn{2}{|c|}{ Vine set B } & \multicolumn{2}{|c|}{ Vine set $\mathrm{A}$} & \multicolumn{2}{|c|}{ Vine set $B$} \\
\hline & & & & & & & & & 1.90 & (GYP) & & & & \\
\hline & & & & & & & 1.7 & (GYP) & & & & & & \\
\hline & & Sporobolomyces roseus & 1.18 & (GYP) & 1.18 & (GYP) & 2.18 & (GYP) & 1.30 & (GYP) & 0.70 & (GYP) & 2.54 & (GYP) \\
\hline & Ascomycetes & Aureobasidium pullulans & 2.70 & (GYP) & 1.60 & (GYP) & 2.65 & (GYP) & 1.00 & (GYP) & 1.00 & (GYP) & 2.00 & (GYP) \\
\hline & & Candida stellimalicola & $\mathrm{na}^{\mathrm{a}}$ & (EBB) & na & (EBB) & & & & & & & & \\
\hline & & Candida zemplinina & na & (EBB) & 1.78 & (GYP) & & & 3.02 & (GYP) & 2.19 & (GYP) & 2.00 & (GYP) \\
\hline & & Hanseniaspora guilliermondii & & & & & na & (EBB) & & & & & & \\
\hline & & Hanseniaspora uvarum & & & 3.14 & (GYP) & na & (EBB) & 2.74 & (GYP) & 1.00 & (DBDM) & & \\
\hline & & Pichia burtonii & & & & & 1.48 & (GYP) & & & & & & \\
\hline & & Saccharomycopsis vini & & & 1.00 & (GYP) & & & & & 1.18 & (DBDM) & & \\
\hline & & Total yeast counts & 2.70 & & 3.19 & & 2.88 & & 3.23 & & 2.23 & & 2.74 & \\
\hline \multirow[t]{19}{*}{ Sour rot } & Ascomycetes & Aureobasidium pullulans & & & & & 4.7 & (GYP) & & & & & & \\
\hline & & Candida amapae & & & 2.74 & (DBDM) & & & & & & & & \\
\hline & & Candida diversa & 3.90 & $(\mathrm{ZDM})$ & 3.60 & (GYP) & & & & & & & & \\
\hline & & Candida frutus & & & & & & & 4.00 & (GYP) & & & & \\
\hline & & Candida stellimalicola & & & na & $(\mathrm{EBB})$ & na & $(\mathrm{EBB})$ & & & & & & \\
\hline & & Candida zemplinina & 5.71 & (GYP) & 5.16 & (GYP) & 6.41 & (GYP) & 6.78 & (GYP) & 6.95 & (GYP) & 6.76 & (GYP) \\
\hline & & Hanseniaspora guilliermondii & na & (EBB) & & & & & na & (EBB) & & & & \\
\hline & & Hanseniaspora uvarum & 6.11 & (GYP) & 5.11 & (GYP) & 6.26 & (GYP) & 6.48 & (GYP) & 6.70 & (GYP) & 6.34 & (GYP) \\
\hline & & Issatchenkia terricola & 5.16 & (GYP) & 3.88 & (GYP) & 5.65 & (GYP) & 6.30 & (GYP) & 5.81 & (GYP) & 5.00 & (GYP) \\
\hline & & Issatchenkia orientalis & na & (EBB) & na & $(\mathrm{EBB})$ & na & (EBB) & 2.74 & (ZDM) & na & $(\mathrm{EBB})$ & & \\
\hline & & Issatchenkia occidentalis & & & & & na & (EBB) & na & (EBB) & 4.55 & (ZDM) & 2.78 & $(\mathrm{ZDM})$ \\
\hline & & Pichia deserticola & & & & & & & & & 3.48 & (ZDM) & 3.84 & (ZDM) \\
\hline & & Pichia guilliermondii & & & & & & & na & $(\mathrm{EBB})$ & 4.53 & (DBDM) & & \\
\hline & & Saccharomycopsis crataegensis & & & & & & & & & & & 3.70 & $(\mathrm{DBDM})$ \\
\hline & & Saccharomycopsis vini & 4.98 & (GYP) & 3.18 & (GYP) & 5.40 & (GYP) & 5.30 & (GYP) & & & 6.00 & (GYP) \\
\hline & & Zygosaccharomyces bailii & & & & & na & (EBB) & & & na & $(\mathrm{EBB})$ & na & $(\mathrm{EBB})$ \\
\hline & & Zygoascus hellenicus & & & 1.60 & (DBDM) & 4.67 & (DBDM) & 4.93 & (DBDM) & 3.81 & (DBDM) & 3.40 & (DBDM) \\
\hline & & Zygoascus meyerae & & & & & 4.27 & $(\mathrm{ZDM})$ & 4.52 & $(\mathrm{ZDM})$ & & & & \\
\hline & & Total yeast counts & 6.34 & & 5.46 & & 6.71 & & 7.04 & & 7.15 & & 6.98 & \\
\hline
\end{tabular}

a na - not applicable (isolated after enrichment step).

Cryptococcus laurentii and Cr. magnus were only recovered at the middle of ripening. These species are typical phylloplane colonists (Fonseca and Inácio, 2006; Nakase, 2000). In particular, S. roseus and $\mathrm{Cr}$. laurentii are the dominant species of the epiphytous complex, i.e. the yeasts that occur on living, green aboveground plant parts (mainly the phylloplane), and regarded as non-geographic (similar species composition in different zones) (Babjeva and Chernov, 1995; De la Torre et al., 1999; Maksimova and Chernov, 2004; Yanagida et al., 1992). Seven ascomycetous yeast species were also recovered from sound grape samples during maturation. Aureobasidium pullulans was the single species isolated in every ripening phase and in all vine sets. This ascomycetous yeast-like fungus is a common inhabitant of the phylloplane (McGrath and Andrews, 2006) and one of the most widespread and well-adapted saprophytes in the phyllosphere (Andrews et al., 1994). Our results are in agreement with Prakitchaiwattana et al. (2004), which refer to A. pullulans as the main species isolated from immature, mature, and both damaged and undamaged grapes. C. zemplinina and H. uvarum were also isolated in the three ripening phases. However, our results seem to demonstrate that these species may have a less homogeneous distribution on grape surfaces, since they were not detected in some vine sets. The predominance of basidiomycetous Rhodotorula spp., Sporobolomyces spp. and Cryptococcus spp., along with A. pullulans, C. zemplinina and $H$. uvarum was also reported by Raspor et al. (2006) and Čadež et al. (2010). Our results also revealed the existence of low populations of Candida stellimalicola, H. guilliermondii and Pichia burtonii, detected in immature sound grapes and S. vini, in both immature and mature grapes (Table 1).

In the case of sour rot damaged grapes, total yeast counts and yeast diversity species in rotten grape samples were much higher than those found in sound grapes. Total yeast counts increased slightly during grape maturation, ranging from $5.9 \log \mathrm{CFU} / \mathrm{g}$, just after veraison, to $7.06 \mathrm{log} \mathrm{CFU} / \mathrm{g}$ in harvest (average values of both vine sets). The highest diversity of yeasts was found at the middle of ripening phase. At this stage, 14 different ascomycetous species were isolated, in contrast with the 10 and 11 species found just after veraison and harvest time, respectively, suggesting that final maturation stages provides a more restrictive environment. A total of 12 ascomycetous yeast species were only recovered from rotten grapes: C. amapae, C. diversa, C. frutus, I. occidentalis, I. orientalis, I. terricola, P. deserticola, P. guilliermondii, S. crataegensis, Z. bailii, Z. hellenicus and $Z$. meyerae. Concerning the isolation frequency, 6 species were isolated in all ripening phases: C. zemplinina, H. uvarum, I. terricola, I. orientalis, S. vini and Z. hellenicus. From this group, the first 3 species were consistently isolated in all grapes sampling sets and registered the highest counts (Table 1 ).

The isolation approach followed in this study, using several culture media in order to maximize the recovery of both major and minority species, was successfully applied. Indeed, $Z$. hellenicus and $Z$. meyerae, were only recovered in DBDM and ZDM media, while the minority species $C$. stellimalicola, $H$. guilliermondii and the dangerous wine spoilage yeast $Z$. bailii (Loureiro and Malfeito-Ferreira, 2003) were isolated only after enrichment phase in EBB medium.

The recovery of $P$. guilliermondii was achieved using DBDM medium and after enrichment in EBB. We have already isolated it from sound, sour rotten and honeydew damaged grapes in the vineyard (Barata et al., 2008a,b), grape musts, grape stems, wines and insects using DBDM (Dias et al., 2003b; Martorell et al., 2006) and Nisiotou et al. (2007) isolated it from the beginning and middle of healthy fermenting musts.

Z. hellenicus and Issatchenkia spp. have been consistently isolated only from sour rotten grapes in a 4-year study (2002 to 2005 vintages) recently performed by Barata et al. (2008a; 2008b). The results described here confirm the high frequency of isolation of $Z$. hellenicus and Issatchenkia spp. only from affected samples, which clearly suggest that these yeasts should be considered as 
zymological markers of sour rotten grapes. Interestingly, Nisiotou and Nychas (2007) in a survey of yeast populations residing on healthy and Botrytis-infected grapes, found that the grey rotten grape samples had higher yeast populations and were also associated to the presence of I. occidentalis, I. terricola and Z. bailii.

The occurrence of $S$. cerevisiae is higher when grape skin is damaged (Mortimer and Polsinelli, 1999). However, we could not isolate $S$. cerevisiae from any sample, which confirms, for one hand, the extreme rarity of S. cerevisiae in grapes (Pretorius, 2000), and for the other hand, the difficult in prove its existence by spreading out diluted must on a solid medium (Martini et al., 1996; Mortimer and Polsinelli, 1999). In addition, $D$. bruxellensis was not isolated from grapes despite the use of EEB selective enrichment medium.

\subsection{2. $A A B$ and $L A B$ changes during ripening}

The alteration of the ecological balance induced by sour rot was particularly evidenced by the unequivocal increase of $A A B$ counts on rotten grapes.

Table 2 shows that sound grape samples harbour very low numbers of $A A B$, which were only detected at the middle of ripening $(1.18 \log \mathrm{MPN} / \mathrm{mL}$ ) and on mature grapes $(0.49 \log \mathrm{MPN} / \mathrm{mL}$ ) (average of both vine sets). On the contrary, sour rotten grapes had very high numbers of $A A B$ populations right from the onset of sour rot symptoms (4.18 $\log \mathrm{MPN} / \mathrm{mL}$ ), reaching up to $7.13 \log \mathrm{MPN} / \mathrm{mL}$ at the middle of ripening and decreasing to $5.83 \mathrm{MPN} / \mathrm{mL}$, in average, at harvest. These results are consistent with previous studies, showing that the population size of AAB is typically small $\left(10^{2}-10^{3}\right.$ cells $\left./ \mathrm{g}\right)$ on sound berries but can exceed $10^{6}$ cells/g on damaged grapes (Drysdale and Fleet, 1988; Joyeux et al., 1984; Lafon-Lafourcade and Joyeux, 1981). More recently González et al. (2005) analysed the $A A B$ populations during a vintage characterized by high incidence of grape spoilage and damage caused by unusual rainfall. Similar results were obtained by the authors, which detected 8 and 3 days before harvest, $4.88 \log \mathrm{CFU} / \mathrm{mL}$ and $6.06 \log \mathrm{CFU} / \mathrm{mL}$ counts, respectively, and $4.11 \log \mathrm{CFU} / \mathrm{mL}$ on the harvest day.

Only two AAB species were isolated from the surface of healthy grapes: G. oxydans was detected at the middle of ripening while mature grapes harboured a low population of Ga. saccharivorans. This scenario changed drastically in damaged grapes samples, for which 7 different ABB species were recovered throughout maturation. The diversity of species increased progressively during ripening as the extent of sour rot was rising, and a clear microbial succession was observed: Ga. saccharivorans was the single species found in the early phase of maturation, followed by the presence of Ga. hansenii and $G$. oxydans at the middle of ripening, and ending with the emergence of $\mathrm{Ga}$. intermedius and three different Acetobacter species (A. malorum, A. orleaniensis and A. syzygii). At the harvest period, G. oxydans ( $6.04 \log \mathrm{MPN} / \mathrm{mL}$ in vine set B) was the dominant species in rotten grapes (Table 2). Generally, previous studies correlate spoiled grapes with increased populations of Acetobacter species, mainly A. aceti and A. pasteurianus (Barbe et al., 2001; Joyeux et al., 1984), whereas healthy grapes show low populations of G. oxydans, which has been found on the grape surface in both spoiled and sound grapes in almost all the studies made up to date (Du Toit and Lambrechts, 2002; González et al., 2005; Joyeux et al., 1984; Prieto et al., 2007; Renouf et al., 2005). G. oxydans prefers a sugarrich environment, while Acetobacter species and Gluconacetobacter species prefer ethanol as carbon source (De Ley et al., 1984; Drysdale and Fleet, 1988).

The recently new proposed Ga. saccharivorans (Lisdiyanti et al., 2006) and A. malorum have been detected in grapes by Valera et al. (2011). A. malorum and Ga. hansenii have been recently isolated from cooked grape must for traditional balsamic vinegar production (Gullo and Giudici, 2006) and A. intermedius, transferred to the genus Gluconacetobacter as Ga. intermedius (Yamada, 2000) is a well known $A A B$ isolated from industrial vinegar fermentations (Boesch et al., 1998). Moreover, A. malorum was also isolated from rotting apple by Cleenwerck et al. (2002). A. orleanensis was isolated from rice wine and A. syzygii from vinegar in Asia (Lisdiyanti et al., 2003).

The incidence and populations of LAB on grapes were very low on both healthy and sour rotten grapes. Detectable populations were only found from the middle of ripening phase: 0.87 and $1.42 \mathrm{MPN} / \mathrm{mL}$ (average of both vine sets), in case of sound and rotten grapes, respectively (Table 2 ). However, at the harvest time, results showed a slight trend for higher counts in damaged grapes, increasing from $0.63 \mathrm{MPN} / \mathrm{mL}$ (vine set $\mathrm{B}$ ) to $1.71 \mathrm{MPN} / \mathrm{mL}$ (average of both vine sets). In this study we were only able to isolate Enterococcus species from the surface of both sound and rotten grapes even after using enrichment cultures. Likewise, E. durans were one of the most

Table 2

Changes in bacterial populations on healthy and sour rot grapes during ripening. Results reported as $\log \mathrm{MPN} / \mathrm{mL}$.

\begin{tabular}{|c|c|c|c|c|c|c|c|c|}
\hline \multirow[t]{2}{*}{ Sanitary state } & \multirow[t]{2}{*}{ Bacteria } & \multirow[t]{2}{*}{ Species } & \multicolumn{2}{|c|}{ After veraison } & \multicolumn{2}{|l|}{ Middle } & \multicolumn{2}{|l|}{ Harvest } \\
\hline & & & Vine set $\mathrm{A}$ & Vine set B & Vine set $\mathrm{A}$ & Vine set $B$ & Vine set $\mathrm{A}$ & Vine set $B$ \\
\hline \multirow[t]{9}{*}{ Sound } & \multirow[t]{3}{*}{$\mathrm{AAB}$} & Gluconacetobacter saccharivorans & & & & & 0.63 & 0.36 \\
\hline & & Gluconobacter oxydans & & & 0.97 & 1.38 & & \\
\hline & & Total AAB counts & $\mathrm{nd}^{\mathrm{a}}$ & nd & 0.97 & 1.38 & 0.63 & 0.36 \\
\hline & \multirow[t]{3}{*}{$\mathrm{LAB}$} & Enterococcus durans & & & 1.38 & 0.36 & & \\
\hline & & Enterococcus sp. & & & & & & 0.63 \\
\hline & & Total LAB counts & nd & nd & 1.38 & 0.36 & nd & 0.63 \\
\hline & \multirow{3}{*}{ Other Gram + } & Staphylococcus saprophyticus & & & & & 2.18 & \\
\hline & & Kocuria kristinae & 0.63 & 0.97 & & & 0.36 & 1.38 \\
\hline & & Total counts & 0.63 & 0.97 & nd & nd & 2.18 & 1.38 \\
\hline \multirow[t]{13}{*}{ Sour rot } & \multirow[t]{8}{*}{$\mathrm{AAB}$} & Acetobacter malorum & & & & & 4.04 & 3.38 \\
\hline & & Acetobacter orleaniensis & & & & & 4.66 & \\
\hline & & Acetobacter syzygii & & & & & 4.88 & \\
\hline & & Gluconacetobacter hansenii & & & 5.66 & 7.04 & & \\
\hline & & Gluconacetobacter intermedius & & & & & 5.18 & 4.66 \\
\hline & & Gluconacetobacter saccharivorans & 4.18 & 4.18 & 5.66 & 6.38 & 5.04 & \\
\hline & & Gluconobacter oxydans & & & & 2.97 & & 6.04 \\
\hline & & Total AAB counts & 4.18 & 4.18 & 5.96 & 7.13 & 5.59 & 6.06 \\
\hline & \multirow[t]{3}{*}{$\mathrm{LAB}$} & Enterococcus durans & & & 1.18 & & & \\
\hline & & Enterococcus sp. & & & & 1.66 & 2.04 & 1.38 \\
\hline & & Total LAB counts & nd & nd & 1.18 & 1.66 & 2.04 & 1.38 \\
\hline & \multirow[t]{2}{*}{ Other Gram + } & Kocuria kristinae & 2.66 & 4.66 & 3.18 & 2.97 & 4.66 & 4.04 \\
\hline & & Total counts & 2.66 & 4.66 & 3.18 & 2.97 & 4.66 & 4.04 \\
\hline
\end{tabular}

a $\mathrm{nd}$ - not detected in $1 \mathrm{~mL}$ of grape must. 
frequently isolated species in a broad study on the bacteria associated with wine grapes cultivated in Australia (Bae et al., 2006), and other authors have already described the isolation of $E$. faecium from surface of grape berries at harvest (Renouf et al., 2005) or grape must (Marcobal et al., 2004). In fact, the association of Enterococcus species with the surface of plants, soil and agricultural environments is well documented (Chen et al., 2005). The usual LAB of wine (O. oeni, Lactobacillus spp., Pediococcus spp.) were not detected on grape berries. Other reports showed their rarity in sound or damaged grapes, with counts usually lower than $10^{2} \mathrm{CFU} / \mathrm{g}$ (Bae et al., 2006; Francesca et al., 2011), which justifies the use of enrichment cultures for their current detection (Bae et al., 2006; Renouf et al., 2005; Renouf et al., 2007).

\subsection{Sour rot effect on microbial populations during wine fermentation}

Wine fermentations were performed to emulate common industrial winemaking practices. In particular, $\mathrm{SO}_{2}$ addition and yeast inoculation are both well established practices in winemaking for restricting the growth of indigenous yeasts and bacterial populations.

\subsubsection{Changes in yeast populations during wine fermentation}

The overall results of this survey are listed in Table 3. The first important observation emerged from the results of total yeast count and species diversity found in the "apparently" sound grape musts. Similar total yeast counts were observed both in healthy or $30 \%$ rotten grape must samples. Contrary to the previous low yeast populations sizes found on healthy mature grape samples (2.49 log $\mathrm{CFU} / \mathrm{g}$ in average) (see Table 1 ), the freshly sound grape must sample harboured a total yeast population of $6.12 \mathrm{log} \mathrm{CFU} / \mathrm{g}$ after crushing in cellar equipment, which represent and increment of around 3.6 $\log$ CFU/g (Table 3). This difference should be due either to the contamination of injured berries hidden in apparently sound bunches or to equipment contamination.

A total of 9 ascomycetous yeast species were recovered from the sound must sample (VAT) (Table 3 ). Five of them (A. pullulans, C. zemplinina, $H$. guilliermondii, $H$. uvarum and $S$. vini) had been previously detected on the surface of mature healthy grapes (see Table 1). However, relative high counts of $C$. diversa, $L$. thermotolerans, $M$. pulcherrima and $P$. sporocuriosa were also detected. Similar populations of these last four species were also found on the must sample with $30 \%$ sour rot (Table 3 ).

In case of grape must containing 30\% rotten grapes, a total of 12 ascomycetous yeast species were isolated, from which 4 of them (C. apicola, I. occidentalis, Z. hellenicus and Z. bailii) were not found on sound musts. It should be highlighted the high population of the dangerous spoilage yeast Z. bailii ( $4.18 \log$ CFU/g). These results confirm our observations in previous studies (Barata et al., 2008a,b). The association of $Z$. bailii with rotten grapes was likewise clearly verified by Nisiotou et al. (2007), which isolated this spoilage species from fermentations of Botrytis affected grapes.

As expected, after alcoholic fermentation, most non-Saccharomyces yeasts present on the initial musts disappeared and $S$. cerevisiae populations grew to around $10^{8}$ cells $/ \mathrm{mL}$. Since any intra-specific

Table 3

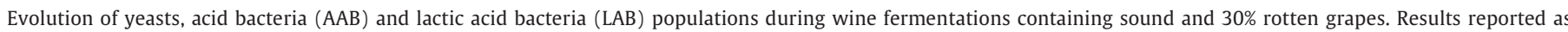
$\log \mathrm{CFU} / \mathrm{ml}$ (yeasts) and $\log \mathrm{MPN} / \mathrm{mL}$ (bacteria).

\begin{tabular}{|c|c|c|c|c|c|c|c|c|c|c|c|c|}
\hline \multirow[t]{3}{*}{ Organism } & \multirow[t]{3}{*}{ Species } & \multirow[t]{3}{*}{ Medium } & \multicolumn{5}{|c|}{$100 \%$ sound grapes vinification ${ }^{a}$} & \multicolumn{5}{|c|}{$30 \%$ Sour rot vinification ${ }^{a}$} \\
\hline & & & \multirow[t]{2}{*}{ VAT } & \multicolumn{2}{|l|}{$\mathrm{AF}$} & \multicolumn{2}{|l|}{ MLF } & \multirow[t]{2}{*}{ VAT } & \multicolumn{2}{|l|}{$\mathrm{AF}$} & \multicolumn{2}{|l|}{ MLF } \\
\hline & & & & $30^{\mathrm{b}}$ & $100^{\mathrm{b}}$ & $30^{\mathrm{b}}$ & $100^{\mathrm{b}}$ & & $30^{\mathrm{b}}$ & $100^{\mathrm{b}}$ & $30^{\mathrm{b}}$ & $100^{\mathrm{b}}$ \\
\hline \multirow[t]{18}{*}{ Yeasts } & Aureobasidium pullulans & GYP & 4.00 & & & & & 4.18 & & & & \\
\hline & Candida apicola & GYP & & & & & & 5.85 & & & & \\
\hline & Candida diversa & GYP & 4.85 & & & & & 5.30 & & & & \\
\hline & Candida pomicola & GYPC & & 1.00 & & & & & & & & \\
\hline & Candida zemplinina & GYP & 6.00 & & & & & 6.49 & & & & \\
\hline & Dekkera bruxellensis & DBDM & & 1.00 & 3.31 & 1.00 & & & 1.00 & & & \\
\hline & Hanseniaspora guilliermondii & DBDM & 1.48 & & & & & & & & & \\
\hline & Hanseniaspora uvarum & GYP & 5.23 & & & & & 5.81 & & & & \\
\hline & Issatchenkia occidentalis & GYP & & & & & & 4.40 & & 1.78 & & \\
\hline & Lachancea thermotolerans & GYP & 4.30 & & & & & 5.00 & & & & \\
\hline & Metschnikowia pulcherrima & GYP & 4.00 & & & & & 3.30 & & & & \\
\hline & Pichia sporocuriosa & ZDM & 3.20 & & & & & 3.75 & & & & \\
\hline & Saccharomyces cerevisiae & GYP & & 8.04 & 8.00 & 4.89 & 4.16 & & 8.09 & 8.00 & 5.72 & 2.81 \\
\hline & Saccharomycopsis vini & GYP & 3.74 & & & & & 4.06 & & & & \\
\hline & Trigonopsis cantarellii & DBDM & & 3.79 & 3.77 & 1.90 & 1.88 & & 3.35 & 3.46 & 1.98 & 1.30 \\
\hline & Zygoascus hellenicus & DBDM & & & & & & 4.60 & & & & \\
\hline & Zygosaccharomyces bailii & ZDM & & & & & & 4.18 & & & & \\
\hline & Total yeast counts (CFU/ml) & GYP & 6.12 & 8.04 & 8.00 & 4.89 & 4.16 & 6.68 & 8.09 & 8.00 & 5.72 & 2.83 \\
\hline \multirow[t]{10}{*}{$\mathrm{AAB}$} & Acetobacter aceti & GY & & 2.04 & & & & & 2.04 & 0.36 & & \\
\hline & Acetobacter cerevisiae & GY & & & & & & 5.04 & 1.38 & & & \\
\hline & Acetobacter malorum & GY & 1.66 & & & & & 4.66 & & & & \\
\hline & Acetobacter tropicalis & GY & & & & & & & 1.38 & & & \\
\hline & Gluconacetobacter europaeus & GY & & & & & & 4.04 & & & & \\
\hline & Gluconacetobacter hansenii & GY & 2.38 & & & & & 6.04 & & & & \\
\hline & Gluconacetobacter intermedius & GY & & & & & & 3.04 & & & & \\
\hline & Gluconacetobacter saccharivorans & GY & 2.66 & & & & & 5.66 & & & & \\
\hline & Gluconobacter oxydans & GY & 3.38 & 2.38 & 3.04 & & & 3.66 & 2.38 & 2.04 & & \\
\hline & Total AAB counts (log MPN/mL) & GY & 3.50 & 2.54 & 3.04 & $\mathrm{nd}^{\mathrm{c}}$ & nd & 6.24 & 2.60 & 2.05 & nd & nd \\
\hline \multirow[t]{5}{*}{ LAB } & Enterococcus durans & MRS & 1.38 & & & & & 2.66 & & & & \\
\hline & Enterococcus sp. & MRS & 2.04 & & & & & 1.38 & & & & \\
\hline & Lactobacillus brevis & MRS & & & & & & & & 0.36 & & \\
\hline & Oenococcus oeni & MRS & & 2.38 & 2.66 & & & & 1.66 & 0.97 & & \\
\hline & Total LAB counts (log MPN/mL) & MRS & 2.13 & 2.38 & 2.66 & nd & nd & 2.68 & 1.66 & 1.06 & nd & nd \\
\hline
\end{tabular}

a VAT: vatting grape must after grapes crushing. Analysis performed prior to commercial yeast and initial $\mathrm{SO}_{2}$ addition; AF: just after alcoholic fermentation; MLF: just after malolactic fermentation and after free $\mathrm{SO}_{2}$ levels adjusted to $40 \mathrm{mg} / \mathrm{L}$.

b Initial $\mathrm{SO}_{2}$ concentration $(\mathrm{mg} / \mathrm{kg})$ added on initial vatting phase.

${ }^{\mathrm{c}}$ nd - not detected in $1 \mathrm{~mL}$ of wine sample. 
typing strain characterization was performed, we cannot guarantee the predominance of the inoculated commercial yeast strain.

The presence of $30 \%$ sour rotten grapes on wine fermentation and the use of higher $\mathrm{SO}_{2}$ concentration $(100 \mathrm{mg} / \mathrm{kg})$ at the initial vatting phase, did not induce significant changes at wine microbiological stability level after alcoholic fermentation and MLF. Besides $S$. cerevisiae, 3 ascomycetous yeasts species were isolated at the end of sound musts fermentations initially sulphited with $30 \mathrm{mg} / \mathrm{kg}$ $\mathrm{SO}_{2}$ : C. pomicola, D. bruxellensis and Trigonopsis cantarellii (syn. Candida cantarellii) (Table 3). These species were not isolated from grapes surfaces or freshly grape musts and thus were probably originated from winery environment/equipment contaminations. Low counts of $D$. bruxellenis and I. occidentalis were detected after fermentation of $30 \%$ rotten musts, however after MLF only viable populations of $T$. cantarellii were observed in all wines. Strains of C. cantarellii sporadically isolated from wine-related environments have been reported as producing traces of 4-ethylphenol in synthetic media (Dias et al., 2003a).

\subsection{2. $A A B$ and $L A B$ changes during wine fermentation}

Low populations of $\mathrm{AAB}(3.50 \log \mathrm{MPN} / \mathrm{mL})$ were found on the freshly sound must sample, characterized by the dominance of G. oxydans and Ga. saccharivorans (Table 3). However, low counts of Ga. hansenii and A. malorum were also obtained. Total AAB counts were significantly higher in the must sample containing $30 \%$ rotten grapes (6.24 $\log \mathrm{MPN} / \mathrm{mL}$ ) and 7 different $\mathrm{AAB}$ species were found: $G$. oxydans, Ga. saccharivorans, Ga. hansenii, Ga. intermedius, $G a$. europaeus, A. cerevisiae and A. malorum. Results show that Ga. hansenii was the dominant species $(6.04 \log \mathrm{MPN} / \mathrm{mL})$ in the rotten must. This species was already mentioned by du Toit and Lambrechts (2002) and González et al. (2004) in wines. Ga. saccharivorans was isolated by Kato et al. (2011) from white wines. The isolation of $A$. cerevisiae was associated to Chilean valleys by Prieto et al. (2007) who speculated that this species may be absent from European vineyards. Our results refute this hypothesis and report for the first time the isolation of this species in musts obtained from grapes collected in European vineyards. Moreover, it is also the first time that Ga. europaeus was found on grape must samples which has been associated, up to date, only to industrial (Sievers et al., 1992) and traditional wine (Vegas et al., 2010) and balsamic (Gullo et al., 2009) vinegars sources.

Alcoholic fermentation induced a strong reduction in $A A B$ populations, which fell to around $2.5 \log \mathrm{MPN} / \mathrm{mL}$ (average of the four trials), confirming the general trend commonly described (Drysdale and Fleet, 1989; Du Toit and Lambrechts, 2002). It appears that the anaerobic conditions due to the vigorous production of carbon dioxide by yeasts during fermentation, restrict the growth of $A A B$ and the ethanol increasing concentration select the most resistant species (González et al., 2005).

Table 3 shows that none of the Gluconacetobacter species survived after fermentation and that $G$. oxydans and $A$. aceti were the dominant species in the wine obtained from both sound and 30\% rotten grape musts added with $30 \mathrm{mg} / \mathrm{kg} \mathrm{SO}_{2}$. In case of rotten wines low populations of $A$. cerevisiae and $A$. tropicalis were also found. The addition of $100 \mathrm{mg} / \mathrm{kg} \mathrm{SO}$ on both freshly musts did not allow the inactivation of $G$. oxydans while A. aceti was reduced by about $2 \log$ counts.

Low LAB populations were observed in the initial must samples, and the presence of sour rot grapes did not led to a significant increase in LAB counts. 0 . oeni was not isolated from freshly grape musts where only Enterococcus spp. were present (Table 3 ) in agreement with Bae et al. (2006). Moreover, these authors showed that E. durans and other Enterococcus species were the most frequently isolated LAB species from grapes. Just after fermentation, Enterococcus species disappeared and 0 . oeni become the dominant LAB species. Low $L$. brevis populations were detected after fermentation of rotten musts added with $100 \mathrm{mg} / \mathrm{kg} \mathrm{SO}$, which show that $\mathrm{LAB}$ were not inhibited by higher $\mathrm{SO}_{2}$ concentrations. After the completion of MLF and subsequent adjustment of the free $\mathrm{SO}_{2}$ levels to $40 \mathrm{mg} / \mathrm{L}$, no viable populations of $A A B$ and $L A B$, including $O$. oeni, were detected in $1 \mathrm{~mL}$ of all analysed wine samples (Table 3 ).

\section{Conclusions}

The results obtained in this work support our view that grape damage is the main driving force altering berry microbiota. Grape damage increases sugar accessibility and creates opportunities for new species to become established. Moreover, we believe that many of the apparently contradictory results found on literature regarding the factors affecting yeast diversity on grapes, may be explained by using grape bunches without separating damaged berries. Undoubtedly, deep changes on the yeast microbiota and on the AAB populations were detected right from the earliest phases of the rotting process, mainly characterized by a noteworthy increase in species diversity and population sizes.

\section{Acknowledgements}

This work was partially funded by the Portuguese Science and Technology Foundation (FCT) and by POCI 2010, participated by the European fund FEDER under the projects POCI/AGR/56771/2004 and PTDC/AGR-ALI/101393/2008. A. Barata was the recipient of a PhD grant (Ref. SFRH/BD/28451/2006) from the FCT.

\section{Appendix A. Supplementary data}

Supplementary data to this article can be found online at doi:10. 1016/j.ijfoodmicro.2011.12.029.

\section{References}

Andrews, J.H., Harris, R.F., Spear, R.N., Lau, G.W., Nordheim, E.V., 1994. Morphogenesis and adhesion of Aureobasidium pullulans. Canadian Journal of Microbiology 40, 6-17.

Babjeva, I.P., Chernov, I.Y., 1995. Geographic aspects of yeast ecology. Physiology and General Biology Reviews 9, 1-54.

Bae, S., Fleet, G.H., Heard, G.M., 2006. Lactic acid bacteria associated with wine grapes from several Australian vineyards. Journal of Applied Microbiology 100, 712-727.

Barata, A. González, S., Malfeito-Ferreira, M., Querol, A., Loureiro, V., 2008a. Sour rotdamaged grapes are sources of wine spoilage yeasts. FEMS Yeast Research 8, 1008-1017.

Barata, A., Seborro, F., Belloch, C., Malfeito-Ferreira, M., Loureiro, V., 2008b. Ascomycetous yeast species recovered from grapes damaged by honeydew and sour rot. Journal of Applied Microbiology 104, 1182-1191.

Barbe, J.C., de Revel, G., Joyeux, A., Bertrand, A., Lonvaud-Funel, A., 2001. Role of botrytized grape micro-organisms in $\mathrm{SO}_{2}$ binding phenomena. Journal of Applied Microbiology 90, 34-42.

Bisiach, M., Minervini, G., Zerbetto, F., 1986. Possible integrated control of grapevine sour rot. Vitis $25,118-128$.

Bisiach, M., Minervini, G., Salomone, M.C., 1982. Recherches expérimentales sur la pourriture acide de la grappe et sur rapports avec la pourriture grise. EPPO Bulletin $12,5-28$.

Blancard, D., Gravot, E., Jailloux, F., Fermaud, M., 2000. Etiology of sour rot in vineyards located in South-West of France. IOBC/wprs Bulletin "Integrated Control in Viticulture" 23, 51-54.

Boesch, C., Trcek, J., Sievers, M., Teuber, M., 1998. Acetobacter intermedius, sp. nov. Systematic and Applied Microbiology 21, 220-229.

Cadez, N., Raspor, P., de Cock, A.W.A.M., Boekhout, T., Smith, M.T., 2002. Molecular identification and genetic diversity within species of the genera Hanseniaspora and Kloeckera. FEMS Yeast Research 1, 279-289.

Čadež, N., Zupan, J., Raspor, P., 2010. The effect of fungicides on yeast communities associated with grape berries. FEMS Yeast Research 10, 619-630.

Chen, Y.S., Yanagida, F., Shinohara, T., 2005. Isolation and identification of lactic acid bacteria from soil using an enrichment procedure. Letters in Applied Microbiology 40, 195-200.

Cleenwerck, I., Vandemeulebroecke, K., Janssens, D., Swings, J., 2002. Re-examination of the genus Acetobacter, with descriptions of Acetobacter cerevisiae sp. nov. and Acetobacter malorum sp. nov. International Journal of Systematic and Evolutionary Microbiology 52, 1551-1558.

Cryer, D.R., Ecclesmall, R., Marmur, J., 1975. Isolation of yeast DNA. In: Prescott, D.M. (Ed.), Methods in Cell Biology, vol. 12. Academic Press, New York, p. 39. 
De la Torre, M., Millan, M., Perez-Juan, P., Morales, J., Ortega, J., 1999. Indigenous yeasts associated with two Vitis vinifera grape varieties cultured in southern Spain. Microbios 100, 27-40.

De Ley, J., Gillis, M., Swings, J., 1984. Family VI. Acetobacteriaceae Gillis and De Ley, 1980, 9th ed. In: Holt, J.G. (Ed.), Bergey's Manual of Systematic Bacteriology, vol. 1. Williams and Wilkins Co., Baltimore, MD, pp. 267-278.

Dias, L., Dias, S., Sancho, T., Stender, H., Querol, A., Malfeito-Ferreira, M., Loureiro, V., 2003a. Identification of yeasts isolated from wine-related environments and capable of producing 4-ethylphenol. Food Microbiology 20, 567-574.

Dias, L., Pereira-da-Silva, S., Tavares, M., Malfeito-Ferreira, M., Loureiro, V., 2003b. Factors affecting the production of 4-ethylphenol by the yeast Dekkera bruxellensis in enological conditions. Food Microbiology 20, 377-384.

Drysdale, G.S., Fleet, G.H., 1988. Acetic acid bacteria in winemaking: a review. American Journal of Enology and Viticulture 39, 143-154.

Drysdale, G.S., Fleet, G.H., 1989. The effect of acetic acid bacteria upon the growth and metabolism of yeasts during the fermentation of grape juice. Journal of Applied Microbiology 67, 471-481.

Du Toit, W.J., Lambrechts, M.G., 2002. The enumeration and identification of acetic acid bacteria from South African red wine fermentations. International Journal of Food Microbiology 74, 57-64.

Esteve-Zarzoso, B., Belloch, C., Uruburu, F., Querol, A., 1999. Identification of yeasts by RFLP analysis of the 5.8S rRNA gene and the two ribosomal internal transcribed spacers. International Journal of Systematic Bacteriology 49, 329-337.

Fonseca, Á., Inácio, J., 2006. Phylloplane yeasts. In: Péter, G., Rosa, C. (Eds.), Biodiversity and Ecophysiology of Yeasts. Springer, Berlin Heidelberg, pp. 263-301.

Francesca, N., Settanni, L., Sannino, C., Aponte, M., Moschetti, G., 2011. Ecology and technological capability of lactic acid bacteria isolated during Grillo grape vinification in the Marsala production area. Annals of Microbiology 61, 79-84.

Fugelsang, K.C., 1997. Wine Microbiology. Chapman \& Hall, New York.

González, Á., Guillamón, J.M., Mas, A., Poblet, M., 2006. Application of molecular methods for routine identification of acetic acid bacteria. International Journal of Food Microbiology 108, 141-146.

González, Á., Hierro, N., Poblet, M., Mas, A., Guillamón, J.M., 2005. Application of molecular methods to demonstrate species and strain evolution of acetic acid bacteria population during wine production. International Journal of Food Microbiology 102, 295-304.

González, Á., Hierro, N., Poblet, M., Rozes, N., Mas, A., Guillamón, J.M., 2004. Application of molecular methods for the differentiation of acetic acid bacteria in a red wine fermentation. Journal of Applied Microbiology 96, 853-860.

Gravot, E., Blancard, D., Fermaud, M., Lonvaud, A., Joyeux, A., 2001. La Pourriture acide. I. Étiologie: recherche de causes de cette pourriture dans le vignoble bordelaise. Phytoma 543, 36-39.

Guerzoni, E., Marchetti, R., 1987. Analysis of yeast flora associated with grape sour rot and of the chemical disease markers. Applied and Environmental Microbiology 53, 571-576.

Guerzoni, M.E., Marchetti, R., 1982. Microflora associata al marciume acido della vite e modificazioni indotte dalla malattia sulla composizione di uve e mosti. Difesa Piante 4, 231-246.

Gullo, M., De Vero, L., Giudici, P., 2009. Succession of selected strains of Acetobacter pasteurianus and other acetic acid bacteria in traditional balsamic vinegar. Applied and Environmental Microbiology 75, 2585-2589.

Gullo, M., Giudici, P., 2006. Isolation and selection of acetic acid bacteria strains for traditional balsamic vinegar. Industrie Delle Bevande 35, 345-350.

Hall, T., 1999. BioEdit: a user-friendly biological sequence alignment editor and analysis program for Windows 95/NT. Nucleic Acids Symposium Series 41, 95-98.

Henick-Kling, T., 1993. Malolactic fermentation. In: Fleet, G.H. (Ed.), Wine Microbiology and Biotechnology. Harwood Academic Publisher, Switzerland, pp. 289-326.

Joyeux, A., Lafon-Lafourcade, S., Ribereau-Gayon, P., 1984. Evolution of acetic acid bacteria during fermentation and storage of wine. Applied and Environmental Microbiology 48, 153-156.

Kato, S., Ishihara, T., Hemmi, H., Kobayashi, H., Yoshimura, T., 2011. Alterations in D-amino acid concentrations and microbial community structures during the fermentation of red and white wines. Journal of Bioscience and Bioengineering 111, 104-108.

König, H., Fröhlich, J., 2009. Lactic acid bacteria. In: König, H., Unden, G., Fröhlich, J. (Eds.), Biology of Microorganisms on Grapes, in Must and in Wine. Springer, Heidelberg, Germany, pp. 3-30.

Kurtzman, C.P., 2003. Phylogenetic circumscription of Saccharomyces, Kluyveromyces and other members of the Saccharomycetaceae, and the proposal of the new genera Lachancea, Nakaseomyces, Naumovia, Vanderwaltozyma and Zygotorulaspora. FEMS Yeast Research 4, 233-245.

Kurtzman, C.P., Fell, J.W. (Eds.), 1998. The Yeasts, A Taxonomic Study. Elsevier, Amsterdam.

Kurtzman, C.P., Robnett, C.J., 1998. Identification and phylogeny of ascomycetous yeasts from analysis of nuclear large subunit (26S) ribosomal DNA partial sequences. Antonie Van Leeuwenhoek 73, 331-371.

Lafon-Lafourcade, S., Carre, E., Ribereau-Gayon, P., 1983. Occurrence of lactic acid bacteria during the different stages of vinification and conservation of wines. Applied and Environmental Microbiology 46, 874-880.

Lafon-Lafourcade, S., Joyeux, A., 1981. Les bactéries acétiques du vin. Bulletin de L'Office International de la vigne et du vin 608, 803-829.

Lisdiyanti, P., Katsura, K., Potacharoen, W., Navarro, R.R., Yamada, Y., Uchimura, T., Komagata, K., 2003. Diversity of acetic acid bacteria in Indonesia, Thailand, and the Philippines. Microbial Culture Collection 19, 91-98.

Lisdiyanti, P., Navarro, R.R., Uchimura, T., Komagata, K., 2006. Reclassification of Gluconacetobacter hansenii strains and proposals of Gluconacetobacter saccharivorans sp. nov. and Gluconacetobacter nataicola sp. nov. International Journal of Systematic and Evolutionary Microbiology 56, 2101-2111.
Lonvaud-Funel, A., 1995. Microbiology of the malolactic fermentation: molecular aspects. FEMS Microbiology Letters 126, 209-214.

Lonvaud-Funel, A., 1999. Lactic acid bacteria in the quality improvement and depreciation of wine. Antonie Van Leeuwenhoek 76, 317-331.

Loureiro, V., Malfeito-Ferreira, M., 2003. Spoilage yeasts in the wine industry. International Journal of Food Microbiology 86, 23-50.

Loureiro, V., Malfeito-Ferreira, M., Carreira, A., 2004. Detecting spoilage yeasts. In: Steele, R. (Ed.), Understanding and Measuring the Shelf-Life of Food. Woodhead Publishers, Cambridge, pp. 233-288.

Maksimova, I.A., Chernov, I.Y., 2004. Community structure of yeast fungi in forest biogeocenoses. Mikrobiologiya 73, 558-566.

Marchetti, R., Guerzoni, E., Gentile, M., 1984. Research on the etiology of a new disease of grapes: sour rot. Vitis 23, 55-65.

Marcobal, Á., de las Rivas, B., García-Moruno, E., Muñoz, R., 2004. The tyrosine decarboxylation test does not differentiate Enterococcus faecalis from Enterococcus faecium. Systematic and Applied Microbiology 27, 423-426.

Martini, A., Ciani, M., Scorzetti, G., 1996. Direct enumeration and isolation of wine yeast from grape surfaces. American Journal of Enology and Viticulture 47, 435-440.

Martorell, P., Barata, A., Malfeito-Ferreira, M., Fernandez-Espinar, M.T., Loureiro, V., Querol, A., 2006. Molecular typing of the yeast species Dekkera bruxellensis and Pichia guilliermondii recovered from wine related sources. International Journal of Food Microbiology 106, 79-84.

McGrath, M.J., Andrews, J.H., 2006. Temporal changes in microscale colonization of the phylloplane by Aureobasidium pullulans. Applied and Environmental Microbiology 72, 6234-6241.

Mortimer, R., Polsinelli, M., 1999. On the origins of wine yeast. Research in Microbiology $150,199-204$

Nakase, T., 2000. Expanding world of ballistosporous yeasts: distribution in the phyllosphere, systematics and phylogeny. The Journal of General and Applied Microbiology 46, 189-216.

Nisiotou, A.A., Nychas, G.J.E., 2007. Yeast populations residing on healthy or Botrytisinfected grapes from a vineyard in Attica, Greece. Applied and Environmental Microbiology 73, 2765-2768.

Nisiotou, A.A., Rantsiou, K., Iliopoulos, V., Cocolin, L., Nychas, G.-J.E., 2011. Bacterial species associated with sound and Botrytis-infected grapes from a Greek vineyard. International Journal of Food Microbiology 145, 432-436.

Nisiotou, A.A., Spiropoulos, A.E., Nychas, G.-J.E., 2007. Yeast community structures and dynamics in healthy and Botrytis-affected grape must fermentations. Applied and Environmental Microbiology 73, 6705-6713.

OIV, 2010. Organisation International de la Vigne et du Vin, Resolution OIV/OENO 206 2010. Microbiological Analysis of Wines and Musts - Revision of Resolution OENO 8/1995, Tbilisi.

Prakitchaiwattana, C.J., Fleet, G.H., Heard, G.M., 2004. Application and evaluation of denaturing gradient gel electrophoresis to analyse the yeast ecology of wine grapes. FEMS Yeast Research 4, 865-877.

Pretorius, I.S., 2000. Tailoring wine yeast for the new millennium: novel approaches to the ancient art of winemaking. Yeast 16, 675-729.

Prieto, C., Jara, C., Mas, A., Romero, J., 2007. Application of molecular methods for analysing the distribution and diversity of acetic acid bacteria in Chilean vineyards. International Journal of Food Microbiology 115, 348-355.

Raspor, P., Milek, D.M., Polanc, J., Smole Mozina, S., Cadez, N., 2006. Yeasts isolated from three varieties of grapes cultivated in different locations of the Dolenjska vinegrowing region, Slovenia. International Journal of Food Microbiology 109, 97-102.

Renouf, V., Claisse, O., Lonvaud-Funel, A., 2005. Understanding the microbial ecosystem on the grape berry surface through numeration and identification of yeast and bacteria. Australian Journal of Grape and Wine Research 11, 316-327.

Renouf, V., Claisse, O., Lonvaud-Funel, A., 2007. Inventory and monitoring of wine microbial consortia. Applied Microbiology and Biotechnology 75, 149-164.

Renouf, V., Lonvaud-Funel, A., 2007. Development of an enrichment medium to detect Dekkera/Brettanomyces bruxellensis, a spoilage wine yeast, on the surface of grape berries. Microbiological Research 162, 154-167.

Ribéreau-Gayon, J., Peynaud, E., Ribéreau-Gayon, P., Sudraud, P., 1972. Analyse et contrôle des vins. Traité d'Oenologie: In: Dunot (Ed.), Sciences et techniques du vin, Paris, vol. I

Rodas, A.M., Ferrer, S, Pardo, I, 2003, 16S-ARDRA, a tool for identification of lactic acid bacteria isolated from grape must and wine. Systematic and Applied Microbiology $26,412-422$.

Rodrigues, N., Gonçalves, G., Pereira-da-Silva, S., Malfeito-Ferreira, M., Loureiro, V., 2001. Development and use of a new medium to detect yeasts of the genera Dekkera/Brettanomyces sp. Journal of Applied Microbiology 90, 588-599.

Ruiz, A., Poblet, M., Mas, A., Guillamón, J., 2000. Identification of acetic acid bacteria by RFLP of PCR-amplified 16S rDNA and 16S-23S rDNA intergenic spacer. International Journal of Systematic and Evolutionary Microbiology 50, 1981-1987.

Sievers, M., Alonso, L., Gianotti, S., Boesch, C., Teuber, M., 1996. 16S-23S ribosomal RNA spacer regions of Acetobacter europaeus and A. xylinum, tRNA genes and antitermination sequences. FEMS Microbiology Letters 142, 43-48.

Sievers, M., Sellmer, S., Teuber, M., 1992. Acetobacter europaeus sp. nov., a main component of industrial vinegar fermenters in central Europe. Systematic and Applied Microbiology and Biotechnology 15, 386-392.

Sipiczki, M., 2004. Species identification and comparative molecular and physiological analysis of Candida zemplinina and Candida stellata. Journal of Basic Microbiology 44, 471-479.

Smith, M.T., 1998. Hanseniaspora Zikes. In: Kurtzman, C.P., Fell, J.W. (Eds.), The Yeasts, a Taxonomic Study. Elsevier Science Publishers, Amsterdam, pp. 214-220.

Valera, M., Laich, F., González, S., Torija, M., Mateo, E., Mas, A., 2011. Diversity of acetic acid bacteria present in healthy grapes from the Canary Islands. International Journal of Food Microbiology 151, 105-112. 
Vegas, C., Mateo, E., González, Á., Jara, C., Guillamón, J.M., Poblet, M., Torija, M.J., Mas, A., 2010. Population dynamics of acetic acid bacteria during traditional wine vinegar production. International Journal of Food Microbiology 138, 130-136.

Wolf, T.K., Zoecklein, B.W., Cook, M.K., Cottingham, C.K., 1990. Shoot topping and ethephon effects on White Riesling grapes and grapevines. American Journal of Enology and Viticulture 41, 330-341.

Yamada, Y., 2000. Transfer of Acetobacter oboediens Sokollek et al. 1998 and Acetobacter intermedius Boesch et al. 1998 to the genus Gluconacetobacter as Gluconacetobacter oboediens comb. nov. and Gluconacetobacter intermedius comb. nov. International Journal of Systematic and Evolutionary Microbiology 50, 2225-2227.
Yanagida, F., Ichinose, F., Shinohara, T., Goto, S., 1992. Distribution of wild yeasts in the white grape varieties at Central Japan. The Journal of General and Applied Microbiology 38, 505-509.

Zoecklein, B.W., Williams, J.M., Duncan, S.E., 2001. Effect of sour rot on the composition of White Riesling (Vitis vinifera L.) grapes. Small Fruits Review 1, 63-77.

Zoecklein, B.W., Wolf, T.K., Duncan, N.W., Judge, J.M., Cook, M.K., 1992. Effects of fruit zone leaf removal on yield, fruit composition, and fruit rot incidence of Chardonnay and White Riesling (Vitis vinifera L.) grapes. American Journal of Enology and Viticulture 43, 139-148. 